\title{
Effects of atmospheric conditions on ice nucleation activity of Pseudomonas
}

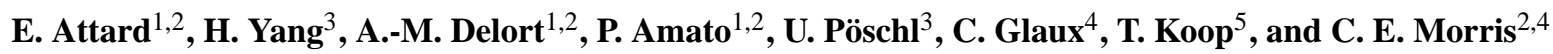 \\ ${ }^{1}$ Clermont Université, Université Blaise Pascal, Institut de Chimie de Clermont-Ferrand, BP 10448, \\ 63000 Clermont-Ferrand, France \\ ${ }^{2}$ CNRS, UMR6296, ICCF, BP 80026, 63171 Aubière, France \\ ${ }^{3}$ Max Planck Institute for Chemistry, Multiphase Chemistry Department, 55128 Mainz, Germany \\ ${ }^{4}$ INRA, UR407 Pathologie Végétale, 84140 Montfavet, France \\ ${ }^{5}$ Bielefeld University, Faculty of Chemistry, 33615 Bielefeld, Germany
}

Correspondence to: C. E. Morris (cindy.morris@avignon.inra.fr), E. Attard (eleonore_attard@hotmail.com)

Received: 9 March 2012 - Published in Atmos. Chem. Phys. Discuss.: 12 April 2012

Revised: 2 September 2012 - Accepted: 29 October 2012 - Published: 16 November 2012

\begin{abstract}
Although ice nuclei from bacterial origin are known to be efficient at the highest temperatures known for ice catalysts, quantitative data are still needed to assess their role in cloud processes. Here we studied the effects of three typical cloud conditions (i) acidic $\mathrm{pH}$ (ii) $\mathrm{NO}_{2}$ and $\mathrm{O}_{3}$ exposure and (iii) UV-A exposure on the ice nucleation activity (INA) of four Pseudomonas strains. Three of the Pseudomonas syringae strains were isolated from cloud water and the phyllosphere and Pseudomonas fluorescens strain CGina01 was isolated from Antarctic glacier ice melt. Among the three conditions tested, acidic $\mathrm{pH}$ caused the most significant effects on INA likely due to denaturation of the ice nucleation protein complex. Exposure to $\mathrm{NO}_{2}$ and $\mathrm{O}_{3}$ gases had no significant or only weak effects on the INA of two $P$. syringae strains whereas the INA of $P$. fluorescens CGina-01 was significantly affected. The INA of the third $P$. syringae strain showed variable responses to $\mathrm{NO}_{2}$ and $\mathrm{O}_{3}$ exposure. These differences in the INA of different Pseudomonas suggest that the response to atmospheric conditions could be strain-specific. After UV-A exposure, a substantial loss of viability of all four strains was observed whereas their INA decreased only slightly. This corroborates the notion that under certain conditions dead bacterial cells can maintain their INA. Overall, the negative effects of the three environmental factors on INA were more significant at the warmer temperatures. Our results suggest that in clouds where temperatures are near $0^{\circ} \mathrm{C}$, the importance of bacterial ice nucleation in precipitation processes could be reduced by some environmental factors.
\end{abstract}

\section{Introduction}

In clouds, ice formation at temperatures above about $-38^{\circ} \mathrm{C}$ occurs via heterogeneous ice nucleation initiated by ice nuclei (IN). Without these IN, water droplets in clouds would remain liquid until $-38^{\circ} \mathrm{C}$, the temperature of spontaneous freezing initiated by homogeneous ice nucleation. A large diversity of particles act as IN in the atmosphere: mineral dust, metallic particles, soot, and biological particles (e.g. DeMott et al., 2003; Möhler et al., 2007; Andreae and Rosenfeld, 2008). Among the biological particles, some bacteria are known as very efficient IN and notably some strains of Pseudomonas syringae which initiate freezing at temperatures as high as $-2{ }^{\circ} \mathrm{C}$ (Orser et al., 1985). The ice nucleation activity (INA) of bacteria is due to a specific protein complex on the bacterial outer membrane that permits efficient arrangement of water molecules into ice embryos. This arrangement is orchestrated by the INA protein which is composed of a repeated octapeptide (Gurian-Sherman and Lindow, 1993). Aggregation of several ice nucleation-active protein modules leads to the formation of a protein complex whose size determines the level of INA: the larger the protein complex the higher the sub-zero temperature at which freezing is induced (Kozloff et al., 1991a; Turner et al., 1990). INA depends on the protein complex being held intact in the outer membrane of the bacteria. This condition is generally met by living cells, but dead cells can also have a high level of INA. This is the case for the commercial adjuvant for production 
of artificial snow, Snomax ${ }^{\circledR}$, a preparation of freeze-dried irradiated cells of $P$. syringae.

Ice nucleation active particles of biological origin have been detected in numerous environments (Bowers et al., 2009; Christner et al., 2008a; Christner et al., 2008b). INA bacteria have also been isolated from a range of substrates including plants (Gross et al., 1983; Kaneda, 1986), aerosols, precipitation (Lindemann et al., 1982; Morris et al., 2008) and from fresh water (Morris et al., 2008; Morris et al., 2010). Microbial species known to be ice nucleation active have been isolated from clouds (Sands et al., 1982; Amato et al., 2006) and their ice nucleation activity was reported in one case (Sands et al., 1982).

In clouds, there are particular environmental conditions such as light intensity and chemistry that could affect bacterial INA. However, quantitative data on such effects are lacking even though they could have considerable consequences for estimations of the impact of biological ice nucleation on cloud processes. Most of the data available on the effects of environmental conditions on bacterial INA are focused on (i) determining ice nucleation protein characteristics and structure (e.g. Turner et al., 1990; Kozloff et al., 1991a, b), (ii) methods to increase ice nucleation active biomass and efficiency for industrial applications in the food industry and in snow making (e.g. Nemecek-Marshall et al., 1993; Blondeaux et al., 1999) and (iii) limiting frost damage to plants (Anderson and Ashworth, 1986; Gurian-Sherman and Lindow, 1993; Kawahara et al., 2000). To our knowledge only the study by O'Brien and Lindow (1988) deviates from this tendency by analyzing the response of bacterial INA submitted to environmental conditions of the natural habitats of these bacteria. These authors observed that INA is sensitive to factors encountered on the plant surface and in particular those related to host plant genotype, light intensity and ambient humidity.

For non-biological ice nucleation particles, ample data are available about the influence of environmental conditions on their activity. For example, several studies have focused on the effects of sulfuric acid coating (Archuleta et al., 2005; Knopf and Koop, 2006; Eastwood et al., 2009), ammonium sulfate coating (Eastwood et al., 2009), organic coating (Kanji et al., 2008; Möhler et al., 2008), and ammonia gas (Salam et al., 2007) on the ice nucleation properties of particles. In certain studies (Kanji et al., 2008; Möhler et al., 2008) organic coating was found to deactivate ice nucleation, whereby a lower temperature is required to initiate ice formation. On the other hand, no common tendency was observed for other coatings and it was shown that effects of sulfuric acid coating depended on the IN material studied (Archuleta et al., 2005; Knopf and Koop, 2006; Eastwood et al., 2009). Therefore, our study aimed at evaluating the effect of key conditions in clouds on bacterial INA. We examined the effects of the $\mathrm{pH}$ of cloud water, UV light and reactive gas exposure on the INA of bacteria isolated from various environments including clouds.
To evaluate the influence of $\mathrm{pH}$ on INA, we took into consideration the range of $\mathrm{pH}$ observed in cloud water. At the summit of the Puy de Dôme, for example, clouds of oceanic origin have a less acidic $\mathrm{pH}(\mathrm{pH} 5.0$ to 6.5) than clouds from the north that are influenced by anthropogenic activities ( $\mathrm{pH} 3.0$ to 4.5 ) (database available at http: //wwwobs.univ-bpclermont.fr/SO/beam/data.php; Marinoni et al., 2004). We hypothesized that acidification of cloud water can decrease the efficiency of bacterial INA probably via the denaturation of the tertiary structure of the ice nucleation protein and/or by an impact on bacterial metabolism.

To evaluate the role of important atmospheric chemical reactions on INA, bacterial strains were exposed to reactive gases. In heavily polluted urban areas there are high levels of $\mathrm{NO}_{2}$ and $\mathrm{O}_{3}$ in the atmosphere. It is known now that proteins can be subjected to oxidation and nitration when exposed to the gas mixtures of $\mathrm{NO}_{2}, \mathrm{O}_{3}$ and water vapor (Franze et al., 2005; Shiraiwa et al., 2011; Shiraiwa et al., 2012). In particular, tyrosine, an aromatic amino acid residue in proteins, can be efficiently nitrated (Walcher et al., 2003; Yang et al., 2010; Zhang et al., 2011). This amino acid residue is part of the water binding site of the ice nucleation protein conferring the tertiary structure with $\beta$-sheet folding at the glycinetyrosine-glycine site (Gazit et al., 2002). In this way the nitration reaction may change the structure of this amino acid that is involved in the tertiary structure of the protein thereby leading to changes in its water-binding capacity and hence its INA efficiency. We exposed bacteria to synthetic gas mixtures of $\mathrm{NO}_{2}$ and $\mathrm{O}_{3}$ at relevant atmospheric concentrations and examined the impact on INA.

To evaluate the effect of UV light, bacterial strains were exposed to UV-A, the most important source of photons in clouds which can cause intense oxidative damage to a range of molecules in bacterial cells (Pourzand and Tyrrell, 1999). We hypothesized that UV-A could affect INA directly via denaturation of the ice nucleation protein exposed on the outer cell membrane or indirectly due to cell death.

\section{Materials and methods}

\subsection{Bacterial strains}

Bacterial strains used in this study originated from three different environments. Strains $13 \mathrm{~b}-2$ and $32 \mathrm{~b}-74$ of $P$. syringae were isolated from cloud water collected at the Puy de Dôme summit (France) in July 2004 and November 2009, respectively. Sampling conditions and isolation methods have been described by Amato et al. (2005) and Vaïtinlingom et al. (2012). The 16S rRNA partial gene sequences of strains $13 \mathrm{~b}-2$ and 32b-74 have been submitted to the GenBank database (accession numbers DQ512785 and HQ256872). Strain P. syringae CC0242 was originally isolated from diseased cantaloupe leaves as described for closely related strains from the same origin (Morris et al., 2000). Strain 
CGina-01 of $P$. fluorescens was isolated from ice melt, provided by C. Foreman (Montana State University), from Cotton Glacier in Antarctica. Snomax ${ }^{\circledR}$ is a commercial preparation containing a freeze-dried and irradiated preparation of a strain of P. syringae (Johnson Controls Inc, Milwaukee, USA). Before ice nucleation assays (described below), bacterial strains were cultured for 3 days at $17^{\circ} \mathrm{C}$ on plates of King's medium B (KB) (King et al., 1954). Bacterial suspensions were prepared with the newly cultivated bacteria in sterile distilled water to obtain $5 \times 10^{8}-5 \times 10^{9}$ cells $\mathrm{mL}^{-1}$. The suspensions were incubated at $4{ }^{\circ} \mathrm{C}$ for at least 1 hour to allow full expression of the ice nucleation protein.

\subsection{Bacterial ice nucleation activity}

Bacterial INA was measured by an immersion freezing test (Vali, 1971). Thirty-two droplets of $20 \mu \mathrm{l}$ of the initial suspension and then 32 droplets of 10 fold serial dilutions of the suspension (from $5 \times 10^{8}$ to $5 \times 10^{3}$ cells mL ${ }^{-1}$ ) were distributed on a sterile aluminum plate and floated on a cooling bath (model F34-ED Julabo, Colmar, France). This serial dilution was performed to allow the calculations described below such that for at least one dilution series, some drops (at least 1) remained unfrozen.

The initial temperature was $-2{ }^{\circ} \mathrm{C}$ and then reduced at $1{ }^{\circ} \mathrm{C}$ intervals until $-10{ }^{\circ} \mathrm{C}$. At each temperature step, the droplets were incubated for $8 \mathrm{~min}$ and at the end of each incubation step the number of frozen droplets was counted visually. The cumulative ice nuclei concentration per bacterial cell at each temperature was calculated according to the method described by Vali (1971) with the following equation: $c(T)=\left[\ln \left(N^{0}\right)-\ln \left(N^{0}-N_{\mathrm{x}}(T)\right)\right] / A$ where $c(T)$ is the number of ice nuclei per bacterial cell active at temperature $T, N^{0}$ is the number of droplets tested, $N_{\mathrm{x}}$ is the number of frozen droplets at a given temperature $T$, and $A$ is the number of bacteria per drop.

Therefore, for each bacterial strain, the level of the INA was determined by (i) the number of ice nuclei per cell and (ii) the highest temperature at which freezing was first observed.

To allow comparison of the INA of bacteria and the mineral compound montmorillonite, we calculated the ice nuclei concentration per surface area, assuming a bacterial surface of $5 \mu \mathrm{m}^{2}$ (considering bacteria as a cylinder of $1 \mu \mathrm{m}$ in length and $0.5 \mu \mathrm{m}$ of radius), and with $30 \mathrm{~m}^{2} \mathrm{~g}^{-1}$ for montmorillonite (Mortazavi et al., 2008). We chose to present the comparison between bacteria and this mineral IN because the publication of Mortazavi et al. (2008) is, to our knowledge, the only study which has applied the immersion freezing assays to mineral compounds.
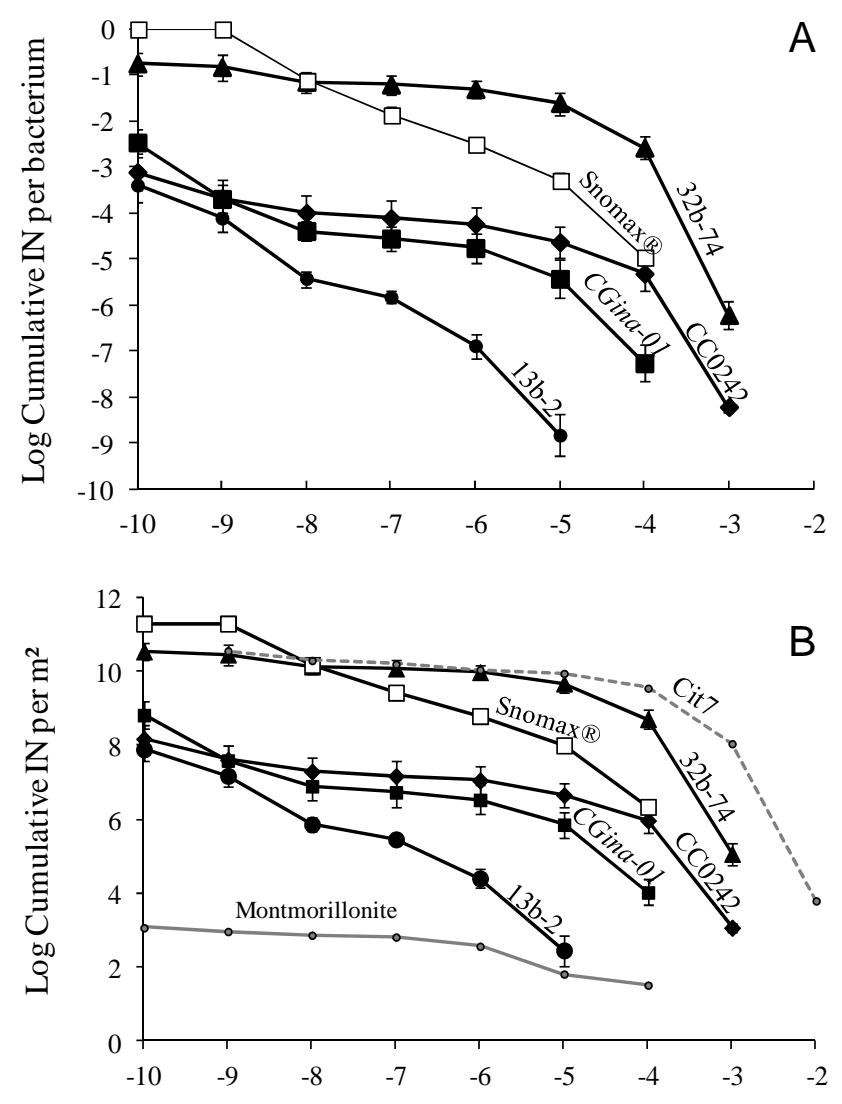

Temperature $\left({ }^{\circ} \mathrm{C}\right)$

Fig. 1. Ice nucleation spectra of Pseudomonas strains in distilled water: $P$. syringae $32 \mathrm{~b}-74 \boldsymbol{\Delta}$ and $13 \mathrm{~b}-2 \bullet, P$. syringae CC0242 $\downarrow, P$. fluorescens CGina-01 $\boldsymbol{\square}$, the commercial Snomax ${ }^{\circledR} \square$, P. syringae Cit7 (grey dotted line; data from Orser et al., 1985) and Montmorillonite (grey solid line, data from Mortazavi et al., 2008). A: log (cumulative IN per bacterium); B: $\log$ (cumulative IN per $\mathrm{m}^{2}$ ). Errors bars indicate standard errors $(n=6)$.

Six replicates were used to calculate the ice nucleation spectra presented in Figs. 1 and 4 replicates for all the experiments concerning $\mathrm{pH}, \mathrm{NO}_{2} / \mathrm{O}_{3}$, and $\mathrm{UV}$ exposure effects.

\subsection{Exposure to acidic $\mathrm{pH}$}

For these experiments, instead of serially diluting in distilled water, the initial bacterial suspension was serially diluted in one of two acetate buffers. The buffer at $\mathrm{pH} 5.9$ was prepared with $93 \mathrm{~mL}$ of sodium acetate at $0.2 \mathrm{M}$ and $7 \mathrm{~mL}$ of acetic acid at $0.2 \mathrm{M}$. The buffer at $\mathrm{pH} 4.1$ was prepared with $18 \mathrm{~mL}$ of sodium acetate at $0.2 \mathrm{M}$ and $82 \mathrm{~mL}$ of acetic acid at $0.2 \mathrm{M}$. Since the original two buffers had different sodium cation concentration, $\mathrm{NaCl}$ was added to the $\mathrm{pH} 4.1$ buffer in order to achieve about the same sodium ion concentration in both buffers.

At room temperature acetic acid is liquid and dissolves in water at all concentrations. The acetic acid/ $\mathrm{H}_{2} \mathrm{O}$ system 
shows a eutectic temperature (ice/acetic acid) of approximately $-26.6^{\circ} \mathrm{C}$ at which point the solubility of acetic acid is about $59 \mathrm{wt} \%$, corresponding to a molality of about $24 \mathrm{~mol} \mathrm{~kg}^{-1}$ (Dahms, 1896). For comparison, the maximum concentration of acetic acid in buffer 2 was only about $0.15 \mathrm{~mol} \mathrm{~kg}^{-1}$. The solubility limit of aqueous sodium acetate solutions is actually determined by the solubility curve of its trihydrate $\left(\mathrm{NaAc} \cdot 3 \mathrm{H}_{2} \mathrm{O}\right)$. At room temperature the solubility is about $5.7 \mathrm{~mol} \mathrm{~kg}^{-1}$ and at the eutectic temperature of $-18^{\circ} \mathrm{C}$ it is $3.7 \mathrm{~mol} \mathrm{~kg}^{-1}$ (Green, 1908). In contrast, the maximum concentration of sodium acetate in buffer 1 was only about $0.17 \mathrm{~mol} \mathrm{~kg}^{-1}$. These calculations show that neither sodium acetate nor acetic acid could have precipitated from the buffer solutions in our experiments upon cooling. We also tested the freezing of buffer - without bacteria adjusted to $\mathrm{pH} 4.1$ and 5.9. For each $\mathrm{pH}, 40$ drops were tested for freezing down to $-10{ }^{\circ} \mathrm{C}$ under the same conditions used to determine the INA of bacterial suspensions. No drops froze under these conditions.

It is well established that solutes affect both homogeneous and heterogeneous ice nucleation through a reduction in the aqueous solution's water activity (Koop et al., 2000; Zobrist et al., 2008). This "colligative" effect on heterogeneous ice nucleation is different from that due to chemical, morphological, or other changes in the IN surface (e.g. the protein complex) induced by the presence of solutes. In order to discriminate between changes in the intrinsic IN properties and colligative effects, we have corrected the data for the colligative effect using a published protocol for estimating its magnitude (Koop and Zobrist, 2009).

First, we calculated the concentration of all ionic and non-ionic solute species introduced by adding the buffer stock solutions described above, also considering the relevant dissociation equilibrium of HAc $\left(\mathrm{Ks}=1.7540 \times 10^{-5}\right)$. Because the total molality of all solute species was less than $0.5 \mathrm{~mol} \mathrm{~kg}^{-1}$ in both cases, we assumed ideal behaviour resulting in $\mathrm{a}_{\mathrm{w}}$ values of 0.99378 and 0.99160 for the $\mathrm{pH} 5.9$ and $\mathrm{pH} 4.1 / \mathrm{NaCl}$ buffers, respectively. The observed freezing behaviour at these water activities was then corrected for the presence of solutes to yield the predicted freezing behaviour in pure water $\left(a_{w}=1\right)$, see Supplement A for details. For example, the cumulative number of IN per bacterium in a pH 5.9 buffer measured at $-3^{\circ} \mathrm{C}$ corresponds to the same cumulative number of IN per bacterium in water at $-2.34^{\circ} \mathrm{C}$. All corrections were smaller than $1^{\circ} \mathrm{C}$. The difference between the measured cumulative number of IN per bacterium in droplets with buffer corrected for solute effects and that measured separately in pure water without buffer is then attributed to the effect of $\mathrm{pH}$ owing to changes induced in the ice nucleating protein complex at the different $\mathrm{pH}$.

\subsection{Exposure to $\mathrm{NO}_{2} / \mathrm{O}_{3}$}

An aliquot of $110 \mu \mathrm{L}$ of the prepared bacterial suspension was introduced into a sterile syringe filter (cellulose acetate membrane, pore size $1.2 \mu \mathrm{m}, 30 \mathrm{~mm}$ diameter, sterile, Whatman $\mathrm{GmbH}$, Dassel, Germany). For each exposure experiment, 6 filters were prepared. They were then dried by a gentle stream of high purity $\mathrm{N}_{2}$ for $\sim 1-2 \mathrm{~h}$. Two filters were kept in a sealed zip-lock bag without exposure to any synthetic gases as control samples to check the effect of exposure to gases with or without $\mathrm{NO}_{2}$ and $\mathrm{O}_{3}$. The other 4 filters were exposed to synthetic gas mixtures overnight (16-18 h). A schematic diagram of the experimental exposure setup is shown in Supplement B. The exposure setup was the same as described in Yang et al. (2010) except that a gas filter system was added upstream of two parallel syringe filters to obtain a synthetic gas mixture free of $\mathrm{O}_{3}$ and $\mathrm{NO}_{2}$. So for each exposure experiment we had 6 samples. Two were control samples without exposure to any synthetic gas. Two of them were exposed to gas mixtures of $108 \pm 2.7 \mathrm{ppb}$ (average value \pm standard deviation) $\mathrm{NO}_{2}$ and $110 \pm 11.3 \mathrm{ppb} \mathrm{O}_{3}$ at the relative humidity $(\mathrm{RH})$ of $\sim 50 \%$, the other two were exposed to filtered synthetic gas mixtures (major compositions: $\mathrm{O}_{2}$ and $\mathrm{N}_{2}$ ) without $\mathrm{O}_{3}$ and $\mathrm{NO}_{2}$ at a slightly reduced RH. After exposure, the filters were immediately washed-off with $1.1 \mathrm{~mL}$ of sterile high purity water. The suspension obtained was subsequently tested for its ice nucleation activity. To an aliquot of $100 \mu \mathrm{L}$ of the remaining suspension, $5 \mu \mathrm{L}$ of a $37 \%(v / v)$ formaldehyde solution was added to fix bacterial cells for counting by flow cytometry.

\subsection{UV exposure}

An aliquot of $30 \mathrm{~mL}$ of the prepared bacterial suspension was placed in a crystallizer $(d=15 \mathrm{~cm}, h=10 \mathrm{~cm})$ with a Pyrex glass lid (thickness $3.3 \mathrm{~mm}$, cut-off wavelength: $290 \mathrm{~nm}$, transparent to UV-A). The crystallizer was surrounded by a plastic circle with 10 aeration tubes to avoid water vapour condensation. In the control experiment, the crystallizer was entirely covered with aluminum foil to avoid UV-A light. Both of the crystallizers were incubated at $17^{\circ} \mathrm{C}$, with gentle shaking (50 rpm) and with UV-A light mimicking the solar spectrum in the atmosphere (i.e. mainly UV-A from 315 to $400 \mathrm{~nm}, 33 \mathrm{~J} \mathrm{~s}^{-1} \mathrm{~m}^{-2}$, with the lamp and solar spectra as described in Vaïtilingom et al., 2011). An aliquot of $1 \mathrm{~mL}$ of the incubated bacterial suspension was taken at $0 \mathrm{~h}, 4 \mathrm{~h}, 20 \mathrm{~h}$ and $42 \mathrm{~h}$ and the ice nucleation activity was measured.

\subsection{Statistical analyses}

One-way ANOVA and Tukey's tests were performed with the PAST software (Hammer et al., 2001) to determine if there were significant differences in the ice nucleation results obtained from different treatments. 


\section{Results}

\subsection{Bacterial ice nucleation activity}

The bacterial strains collected from cloud water at the Puy de Dôme summit, P. syringae 13b-2 and 32b-74 showed marked INA. Both were collected from clouds originating from the French west coast with $\mathrm{pH}$ values of 5.2 and 5.5, respectively. Under our experimental conditions $P$. syringae $32 \mathrm{~b}-$ 74 initiated freezing at $-3^{\circ} \mathrm{C}$ and produced $10^{-0.75} \mathrm{IN}$ per bacterium, i.e. 1 active ice nucleus per 5.7 cells at the coldest temperature tested, $-10^{\circ} \mathrm{C}$ (Fig. 1a). Strain 13b-2, initiated freezing at $-5^{\circ} \mathrm{C}$ and produced two orders of magnitude fewer ice nuclei than strain $32 \mathrm{~b}-74$ at $-10^{\circ} \mathrm{C}\left(10^{-3.4} \mathrm{IN}\right.$ per bacterium, i.e. 1 active nucleus per $2.5 \times 10^{3}$ cells at $-10^{\circ} \mathrm{C}$ ) (Fig. 1a). Strain CC0242 of $P$. syringae isolated from the phyllosphere, strain CGina-01 of $P$. fluorescens from glacial melt and the Snomax ${ }^{\circledR}$ commercial product had freezing profiles intermediate to strains $32 \mathrm{~b}-74$ and 13b-2. Except for strain 32-b74, all these strains had less activity than that of strain Cit7 of $P$. syringae under the conditions used by Orser et al. (1985) (Fig. 1b). However, all of these strains had several orders of magnitude higher ice nucleation activity on a surface area basis than mineral dust e.g. montmorillonite at the temperature range between -3 and $-10^{\circ} \mathrm{C}$ (Fig. 1b, based on previously reported ice nucleation spectra of montmorillonite by Mortazavi et al., 2008). This mineral dust had $10^{3.1}$ ice nuclei per $\mathrm{m}^{2}$ surface area active at $-10^{\circ} \mathrm{C}$ whereas strains 32b-74 and $13 \mathrm{~b}-2$ had $10^{10.4}$ and $10^{7.8}$ ice nuclei per $\mathrm{m}^{2}$ surface area of cell, respectively (Fig. 1b).

\subsection{Effects of acidic $\mathrm{pH}$}

Composition of $\mathrm{pH}$ buffers led to a reduction in ice nucleation temperature of around $0.7^{\circ} \mathrm{C}$ for the $\mathrm{pH} 5.9$ buffer and of around $0.9-1.0^{\circ} \mathrm{C}$ for the $\mathrm{pH} 4.1$ buffer (Supplement C). The effect was slightly temperature dependent (i.e. a larger effect at a lower temperature) (Supplement C). Taking into account water activity corrections, the acidic $\mathrm{pH} 4.1$ strongly reduced the IN number compared to $\mathrm{pH} 5.9$ for the temperature range tested for strains 32b-74, 13b-2, CGina-01 and for Snomax ${ }^{\circledR}$ (Fig. 2). For P. syringae CC0242, IN number at $\mathrm{pH} 4.1$ compared to $\mathrm{pH} 5.9$ was not significantly different. Compared to $\mathrm{pH} 5.9$, the temperature at which freezing began was decreased at $\mathrm{pH} 4.1$ for all strains except $P$. syringae 32b-74 (Fig. 2).

Compared to distilled water, $\mathrm{pH} 5.9$ led to a decrease in the IN number for $P$. syringae 32b-74, P. fluorescens CGina01 at the highest temperatures, and for all temperatures for P. syringae CC0242 (Fig. 2). Compared to distilled water, pH 5.9 led to an increase in the IN number for Snomax ${ }^{\circledR}$ (Fig. 2).

\subsection{Effects of $\mathrm{NO}_{2} / \mathrm{O}_{3}$ exposure}

The number of viable cells of all strains was significantly reduced by gas exposure. Taking into account that dead cells could maintain an efficient ice nucleation protein, INA was calculated by dividing the number of IN by the number of viable cells counted at the beginning of the experiment. In order to check if cells were degraded by gas exposure, the total cell number was counted by flow cytometry. This confirmed that the total cell number of all strains was not significantly affected by gas exposure (data not shown).

In order to evaluate the effect of the exposure systems, comparisons of INA were made between bacteria exposed to synthetic air without $\mathrm{NO}_{2} / \mathrm{O}_{3}$ and bacteria not introduced in the exposure system. After exposure to synthetic air without $\mathrm{NO}_{2}$ and $\mathrm{O}_{3}$, the INA of strains 32b-74 and 13b-2 was not significantly different from that of bacteria (at the same concentration) not introduced into the exposure system (data not shown). For strains CC0242 and CGina-01, after exposure to synthetic air without $\mathrm{NO}_{2}$ and $\mathrm{O}_{3}$, the initial temperature of freezing decreased by $1{ }^{\circ} \mathrm{C}$ and $2{ }^{\circ} \mathrm{C}$, respectively (data not shown).

In order to evaluate the effect of $\mathrm{NO}_{2} / \mathrm{O}_{3}$ exposure, comparisons of INA were made between bacteria exposed to synthetic gas mixtures with and without $\mathrm{NO}_{2} / \mathrm{O}_{3}$. Exposure to $\mathrm{NO}_{2} / \mathrm{O}_{3}$ did not have a significant effect on the INA of strain 13b-2 (Fig. 3). For strain 32b-74, $\mathrm{NO}_{2} / \mathrm{O}_{3}$ exposure caused a decrease of $1{ }^{\circ} \mathrm{C}$ of the temperature at which freezing initially occurred and a slight difference in IN number at $-4{ }^{\circ} \mathrm{C}$ (Fig. 3). In contrast, the INA of CGina-01 was significantly affected by $\mathrm{NO}_{2} / \mathrm{O}_{3}$ exposure with a decrease of $2{ }^{\circ} \mathrm{C}$ in the temperature at which freezing initially occurred (Fig. 3). For CC0242, two different patterns of response were observed between the four replicate trials. In two replicates, the initial temperature at which freezing occurred was not affected by $\mathrm{NO}_{2} / \mathrm{O}_{3}$ exposure whereas it was markedly decreased by $4{ }^{\circ} \mathrm{C}$ in the other two replicates (Fig. 3).

\subsection{Effects of UV-A exposure}

The number of viable cells of strains $32 b-74$ and $13 b-2$ was significantly reduced after $42 \mathrm{~h}$ of UV-A exposure (Fig. 4). Viable cell number of $P$. syringae $\mathrm{CC} 0242$ began to decrease after $20 \mathrm{~h}$ of UV-A exposure. The number of cells of CGina01 decreased significantly from the first sampling point i.e. after $4 \mathrm{~h}$ of UV-A exposure. Whereas the viable cell number of $P$. syringae 32b-74, 13b-2 and CC0242 decreased by a factor of 10 at the end of the UV exposure, the abundance of viable cells of $P$. fluorescens CGina-01 decreased by a factor of 27.

For all strains, UV-A exposure did not lead to any significant effect on INA at $4 \mathrm{~h}$ and $20 \mathrm{~h}$ of exposure (data not shown). At the end of the exposure, no effect of UV-A exposure on the temperature at which freezing initially occurred was observed in any of the strains tested (Supplement D). 

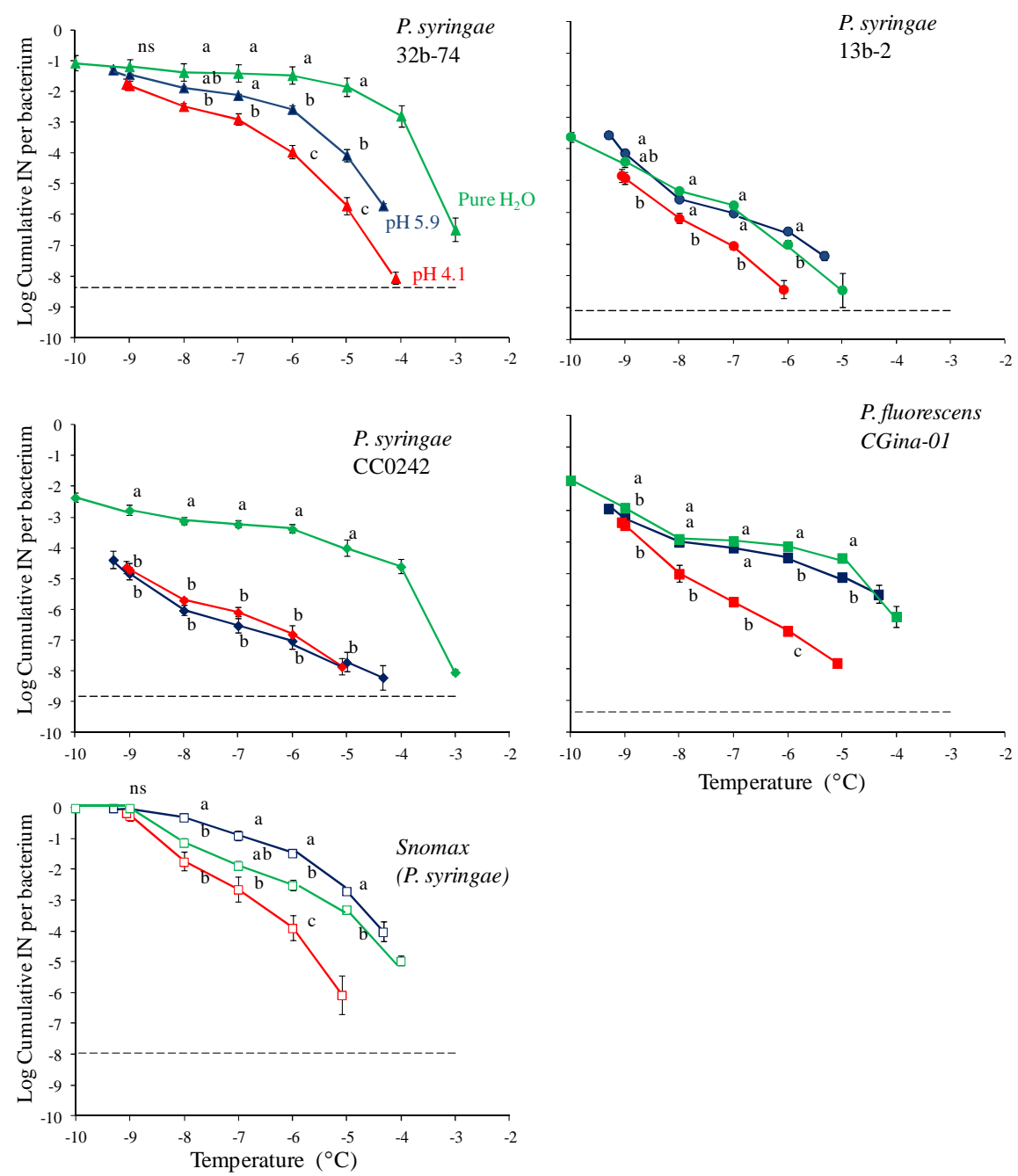

Fig. 2. Ice nucleation spectra of Pseudomonas strains submitted to different $\mathrm{pH}$ : $\mathrm{pH}=4.1$ (red), $\mathrm{pH}=5.9$ (blue) and in distilled water as a control (green). Data were corrected for water activity of the buffer and linearly interpolated. The horizontal line corresponds to the lower limit of detectable activity depending on the initial bacterial concentration of each experiment. Symbols are as in Fig. 1. At each temperature, values associated with different letters are significantly different $(p<0.05)$ based on Tukey's test. ns: no significant treatment effect. Errors bars indicate standard errors $(n=4)$.

INA of 13b-2 was not affected by $42 \mathrm{~h}$ of UV-A exposure (Supplement D). Conversely, the INA of 32b-74, CC0242 and CGina-01 increased after $42 \mathrm{~h}$ of UV-A exposure compared to unexposed control samples. Here, INA after $42 \mathrm{~h}$ of exposure was calculated by dividing the number of IN by the number of viable cells counted after $42 \mathrm{~h}$ of exposure. However, to take into account that dead cells could maintain an efficient ice nucleation protein, INA after $42 \mathrm{~h}$ exposure was also calculated by dividing the number of IN by the number of viable cells counted at the beginning of the experiment (Fig. 5). Consistent with the previous calculation, the INA of 13b-2 was not significantly affected by UV-A (Fig. 5). However, the INA of 32b-74, CC0242 and CGina-01 was slightly reduced by UV-A exposure.

\section{Discussion}

There has been a recent focus of atmosphere modeling on evaluation of the impact of biological ice nuclei on glaciation processes leading to precipitation (Hoose et al., 2010; Sesartic et al., 2011). However this approach is limited by quantitative data on abundance and activity of biological ice nucleators in the atmosphere. Here we reported not only ice nucleation spectra of different bacterial strains but also their response to three environmental conditions typically encountered in clouds. Our results demonstrate that among these conditions, acidic $\mathrm{pH}$ has a strong effect on bacterial INA but UV-A and $\mathrm{NO}_{2} / \mathrm{O}_{3}$ exposure have only little effects. Furthermore, the $\mathrm{pH}$ effects on INA are more evident at higher temperatures but by $-8^{\circ}$ or $-10^{\circ} \mathrm{C}$ the effects are weaker. 

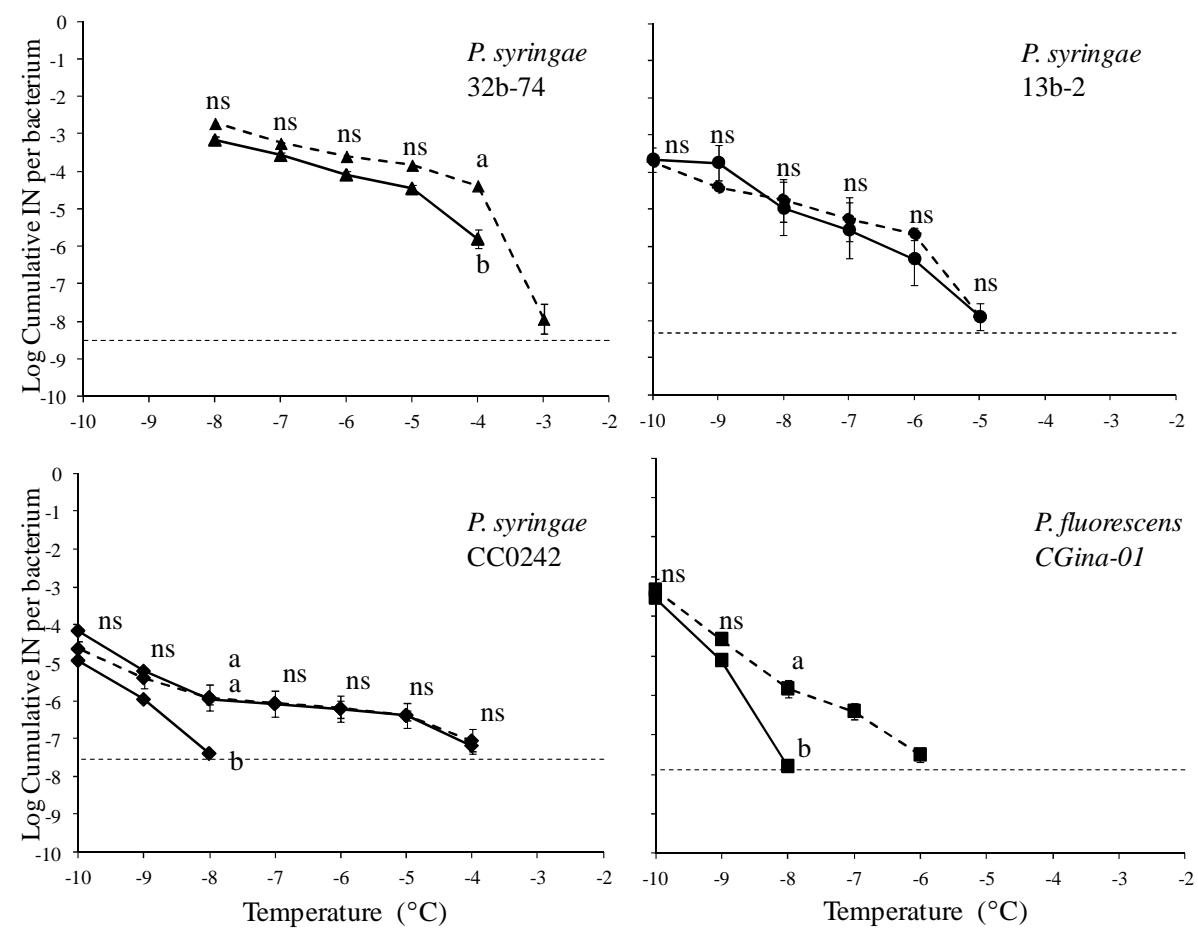

Fig. 3. Ice nucleation spectra of Pseudomonas strains exposed to synthetic gases with (solid line) and without (dotted line) $\mathrm{NO}_{2}$ and $\mathrm{O}_{3}$. The horizontal line corresponds to the lower limit of detectable activity depending on the initial bacterial concentration of each experiment. Symbols are as in Fig. 1. Each symbol corresponds to the mean value of 4 replicates except for $P$. syringae CC0242 that was exposed to gases with $\mathrm{NO}_{2}$ and $\mathrm{O}_{3}$, where symbols correspond to the mean value of 2 replicates. At each temperature, values associated with different letters are significantly different $(p<0.05)$ based on Tukey's test. ns: no significant treatment effect. Errors bars are standard errors $(n=4$, except for $P$. syringae $\mathrm{CC} 0242$ where $n=2)$.
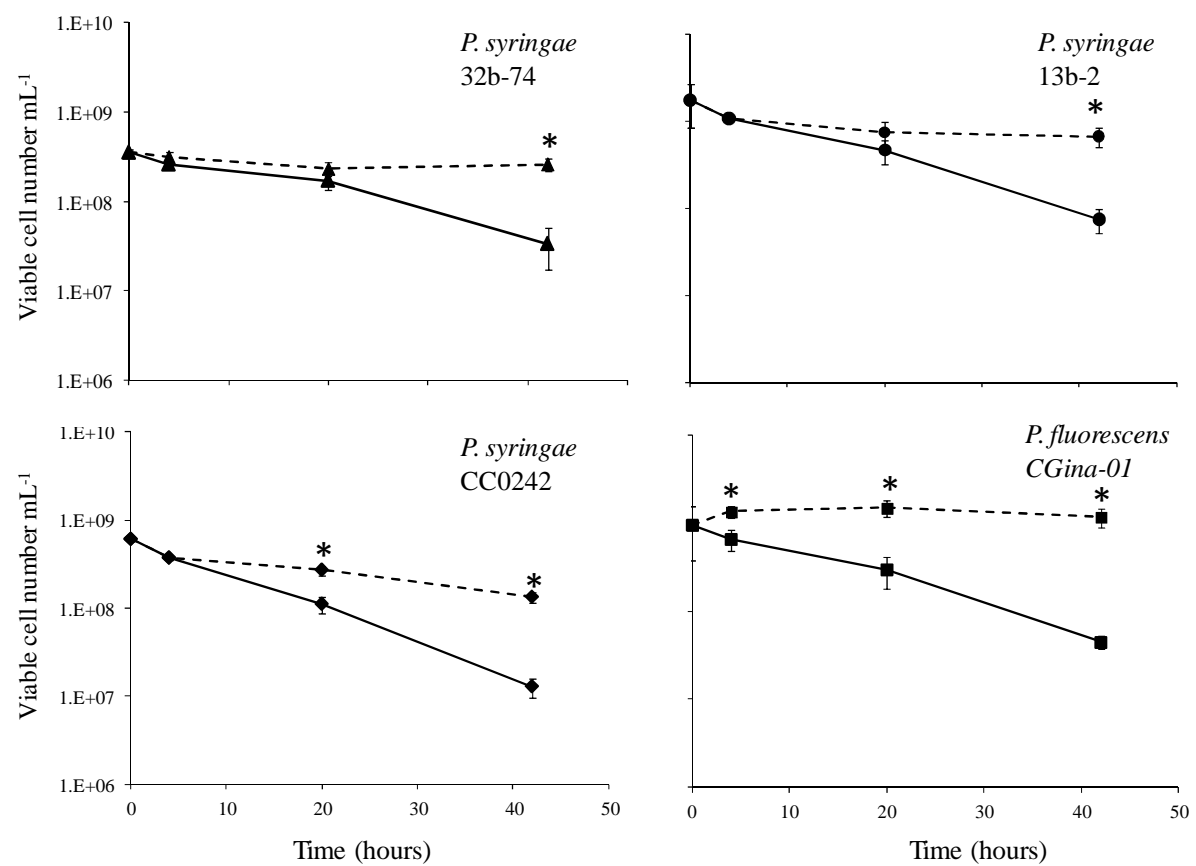

Fig. 4. Viable cell number (CFU) of the Pseudomonas strains after UV exposure (solid line) or darkness (dotted line). Symbols are as in Fig. 1. At each time point, values associated with an asterisk are significantly different $(p<0.05)$ based on Tukey's test. Errors bars are standard errors $(n=4)$. 

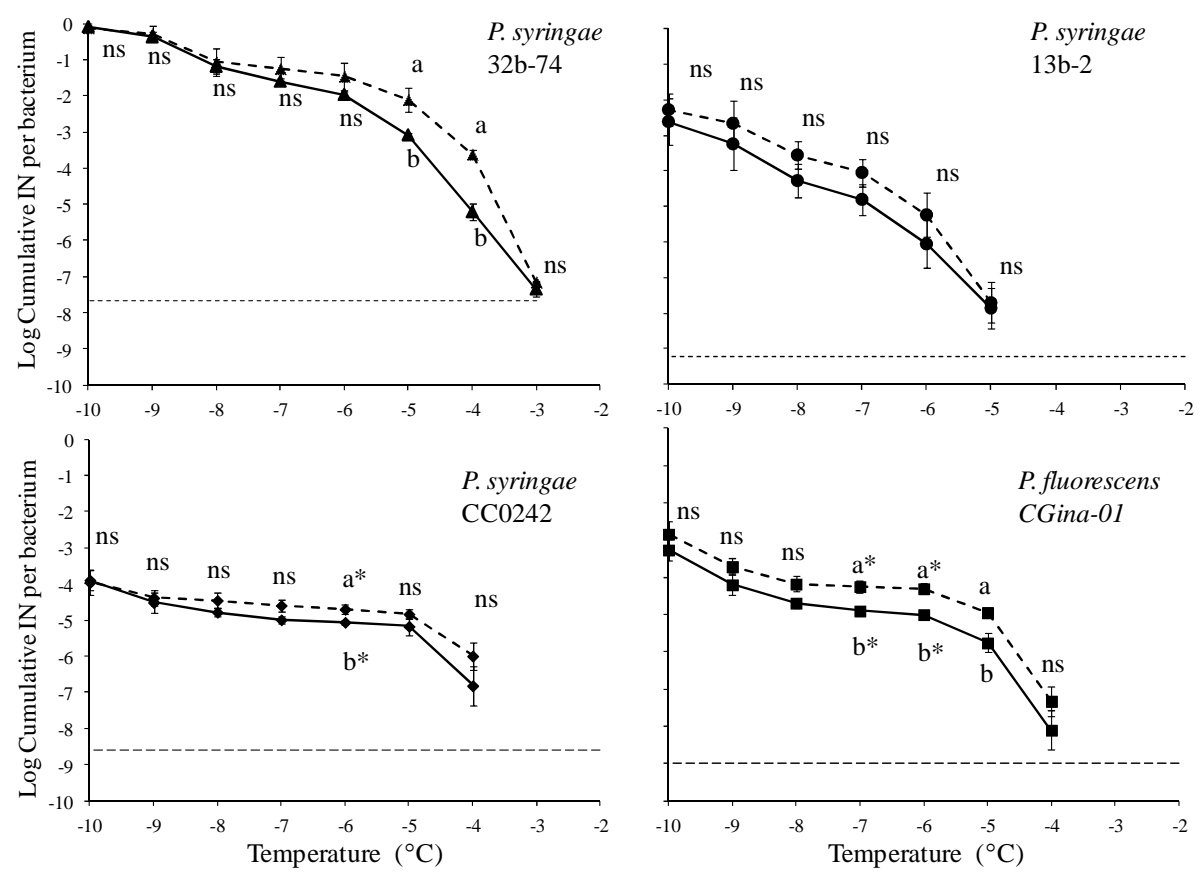

Fig. 5. Ice nucleation spectra of Pseudomonas strains submitted to $42 \mathrm{~h}$ of UV-A exposure (solid line) or darkness (dotted line). The horizontal line corresponds to the lowest value of detectable activity, which depends on the initial bacterial concentration of each experiment. Symbols are as in Fig. 1. INA was calculated by dividing the number of ice nuclei (IN) recorded after $42 \mathrm{~h}$ of UV-exposure by the viable cell number counted at the beginning of the experiment. At each temperature, values associated with different letters are significantly different at $p<0.05$ and those associated with an asterisk are significantly different at $p<0.1$ based on Tukey's test. ns: no significant treatment effect. Errors bars are standard errors $(n=4)$.

In this work we demonstrated that acidic $\mathrm{pH}$ reduced the INA of all the four strains studied and more intensely above $-8^{\circ} \mathrm{C}$. This effect of acidic $\mathrm{pH}$ on INA of Pseudomonas was previously studied by Kozloff et al. (1983) and Kawahara et al. (1995) whose results are consistent with ours. In addition, Turner et al. (1990) reported that effects of acidic $\mathrm{pH}$ were more intense for ice nuclei active at temperatures near $0{ }^{\circ} \mathrm{C}$. They observed that the number of bacterial ice nuclei active at $-4^{\circ} \mathrm{C}$ was severely reduced by acidic $\mathrm{pH}$ whereas those active at $-9^{\circ} \mathrm{C}$ were almost not affected. Similarly, at a colder temperature $\left(-38^{\circ} \mathrm{C}\right)$, no effects of acidic $\mathrm{pH}$ were observed on the IN properties of Snomax ${ }^{\circledR}$ (Chernoff and Bertram, 2010). As it has been proposed that ice nucleation efficiency is linked to the level of aggregation of the ice nucleation protein (Kozloff et al., 1991a) these results suggest that acidic $\mathrm{pH}$ acts via denaturation of the larger protein complexes. Indeed, bacteria expressing INA at the warmer temperatures carry larger protein complexes whereas at colder temperature smaller complexes are more abundant (Kozloff et al, 1991a). Then with acidic pH leading to denaturation of the protein complex, more effect will be observed on the larger complexes active at high temperatures and weaker effects will be observed on the smaller complexes active at cold temperatures. Furthermore, effects of acidic $\mathrm{pH}$ at the warmer temperatures were observed not only on the INA of living bacteria but also on the INA of the non-viable bacterial product Snomax ${ }^{\circledR}$, thereby supporting the hypothesis that acidic $\mathrm{pH}$ affects the INA of bacteria probably by directly changing the ice nucleation protein structure. However, the effects of acidic $\mathrm{pH}$ were less intense on Snomax ${ }^{\circledR}$ than on living bacteria. This suggests that for living cells, acidic $\mathrm{pH}$ likely acts through a combination of direct changes of the ice nucleation protein structure and indirect effects via bacterial metabolism in reaction to acidic conditions.

To more clearly specify the effects of $\mathrm{pH}$ on INA, we took into account the effect on water activity of the solutes used as buffer. Indeed, as shown previously (Zobrist et al., 2008; Koop and Zobrist, 2009) a reduction in water activity is linked to a reduction in the INA of dusts and Snomax ${ }^{\circledR}$. All our data were corrected for water activity of the $\mathrm{pH}$ buffer but, when subjected to $\mathrm{pH} 5.9$, the INA of some strains differed more or less from that in distilled water. For Snomax ${ }^{\circledR}$, a slight positive effect of this $\mathrm{pH}$ buffer on INA was observed. This increase is counterintuitive but could be linked to the complex nature of Snomax ${ }^{\circledR}$ which is a lyophilized product composed of bacteria but also culture medium residues and different wastes which can interact in a complex and still unexplained way with the $\mathrm{pH}$ buffer. 
In contrast to the strong effects of acidic pH on INA, $\mathrm{NO}_{2} / \mathrm{O}_{3}$ exposure did not significantly influence the INA of strains $P$. syringae $32 \mathrm{~b}-74$ and $13 \mathrm{~b}-2$, which seem to indicate that the structure of the IN-inducing protein on the surface of the bacteria was not significantly changed by exposure to the reactive gases $\mathrm{NO}_{2}$ and $\mathrm{O}_{3}$. For $P$. fluorescens a reduction in the temperature at which freezing began was observed. It should be noted that the INA of this strain was already reduced by exposure to the synthetic gases without $\mathrm{O}_{3}$ and $\mathrm{NO}_{2}$. This fragility could account for the greater sensitivity of $P$. fluorescens to exposure to $\mathrm{NO}_{2}$ and $\mathrm{O}_{3}$ gases than of the $P$. syringae strains. The effect on strain CC0242 of $P$. syringae was more complicated than for the others strains: whereas the INA of two replicates was only slightly reduced, the INA of two others replicates was substantially affected by the reactive gas exposure. Variability among tests of INA was reported before. Mortazavi et al. (2008) have suggested that it is likely due to the ability of the ice-nucleating protein to aggregate. Despite the well-controlled conditions of preparation of bacteria for testing, some unidentified parameters may lead to differences in aggregation and thus to variations of INA.

Concerning UV-A exposure, we observed a significant loss of viability for all strains and especially for strain CGina-01 of $P$. fluorescens. Strikingly, this significant loss of viability was not associated with a decrease in INA (calculated with cell number at the beginning of the experiment) further validating the fact that under certain conditions, non viable cells can maintain INA and especially when cell integrity is maintained (Kozloff et al., 1991a). However, it should be noted that certain UV wavelengths can be damaging for INA. As shown by Anderson and Ashworth (1986) the highly lethal UV-C (almost absent in the atmosphere) caused a total loss of viability and a large reduction in INA, contrary to our observation of the effects of UV-A exposure.

\section{Conclusions}

Our results make a contribution to efforts to elucidate the impact of biological ice nucleators on cloud glaciation, but overall they illustrate the need for more in-depth quantification of the abundance and activity of INA organisms in the atmosphere. Firstly, it is interesting to note that two strains used here were isolated from cloud water providing direct evidence of their presence and viability in this environment. Furthermore, not all the $P$. syringae strains isolated in clouds were active as IN contrary to what was observed in snow and rain samples (Morris et al., 2008). This could suggest that INA is not necessarily involved in the incorporation of these bacteria in cloud water whereas it might be for incorporation into precipitation. Our results also illustrate that the ice nucleation activity of Pseudomonas is surprisingly robust in response to atmospheric conditions other than acidity. Hence the data presented here can contribute to efforts to model cloud glaciation processes in that they suggest that the efficiency of some of the biological catalysts of ice formation in clouds might be reduced in clouds acidified by anthropogenic emissions. Such information can be incorporated in regional models but might be difficult to consider in global models. Exposure to other pollutants such as $\mathrm{NO}_{2} / \mathrm{O}_{3}$ seems to have a weaker effect. However, the differences in behaviour that we observed among strains and between the two species studied here suggest that the response to atmospheric conditions is rather strain-specific.

Acidic $\mathrm{pH}$ of atmospheric water droplets is a modern phenomenon due to the strong increase in emissions of $\mathrm{SO}_{2}$ and $\mathrm{NO}_{\mathrm{x}}$ from the $19^{\text {th }}$ century, the beginning of the industrialization era (Smith et al., 2004; Dentener et al., 2006; Lamarque et al., 2010; Skeie et al., 2011). If initiating cloud glaciation processes is part of an adaptive survival and dissemination strategy for air-borne bacteria such as $P$. syringae, then it would be expected that the INA of these bacteria would not be significantly deteriorated by common conditions encountered in the atmosphere - and that likewise there could be selective pressures that will lead to eventual adaptation of $P$. syringae and other IN bacteria to these emerging conditions. Therefore, unlike mineral nucleators, it is feasible that, with continued exposure to atmospheric pollutants, biological ice nucleators in the atmosphere would adapt to the changing atmospheric conditions - and in particular chemical conditions - leading to enhanced efficiency of their INA. The challenge for cloud modelling will be to integrate these dynamic parameters.

\section{Supplementary material related to this article is available online at: http://www.atmos-chem-phys.net/12/ 10667/2012/acp-12-10667-2012-supplement.pdf.}

Acknowledgements. Postdoctoral funding for E. Attard was supplied by the Institut de Chimie de Clermont-Ferrand (France) thanks to CNRS and Blaise Pascal University (UBP) fellowships.

The experiment part with $\mathrm{NO}_{2} / \mathrm{O}_{3}$ exposure was funded by the Max Planck Society (MPG). We acknowledge funding from the joint DFG-CNRS project Bioclouds for T. K. (under KO 2944/1-1), E. A. and A. M. D.

We thank X. Chi, J. Fröhlich, I. Müller, C. Pöhlker, C. Ruzene, for technical support.

We thank C. Foreman (Montana State University) for providing the ice melt sample from which strain CGina-01 was isolated. Publication costs were covered by a grant from the US National Science Foundation Division of Atmospheric and Geospace Sciences to C.E.M.

Edited by: A. Nenes 


\section{References}

Amato, P., Menager, M., Sancelme, M., Laj, P., Mailhot, G., and Delort, A. M.: Microbial population in cloud water at the Puy de Dôme: implications for the chemistry of clouds, Atmos. Environ., 39, 4143-4153, 2005.

Amato P., Parazols M., Sancelme M., Laj P., Mailhot G., and Delort A. M.: Microorganisms isolated from the water phase of tropospheric clouds at the Puy de Dôme: major groups and growth abilities at low temperatures, FEMS Microbiol. Ecol., 59, 242254, 2006

Anderson, J. A. and Ashworth, E. N.: The effects of streptomycin, desiccation, and UV radiation on ice nucleation by Pseudomonas viridiflava, Plant Physiol., 80, 956, 1986.

Andreae, M. O. and Rosenfeld, D.: Aerosol-cloud-precipitation interactions. Part 1. The nature and sources of cloud-active aerosols, Earth-Sci. Rev., 89, 13-41, 2008.

Archuleta, C. M., DeMott, P. J., and Kreidenweis, S. M.: Ice nucleation by surrogates for atmospheric mineral dust and mineral dust/sulfate particles at cirrus temperatures, Atmos. Chem. Phys., 5, 2617-2634, doi:10.5194/acp-5-2617-2005, 2005.

Blondeaux, A., Hamel, J. F., Widehem, P., and Cochet, N.: Influence of water activity on the ice-nucleating activity of Pseudomonas syringae, J. Ind. Microbial. Biot., 23, 514-519, 1999.

Bowers, R. M., Lauber, C. L., Wiedinmyer, C., Hamady, M., Hallar, A. G., Fall, R., Knight, R., and Fierer, N.: Characterization of Airborne Microbial Communities at a High-Elevation Site and Their Potential To Act as Atmospheric Ice Nuclei, Appl. Environ. Microbiol., 75, 5121-5130. 2009.

Chernoff, D. I. and Bertram, A. K.: Effects of sulfate coatings on the ice nucleation properties of a biological ice nucleus and several types of minerals, J. Geophys. Res., 115, D20205, doi:10.1029/2010JD014254, 2010.

Christner, B. C., Cai, R., Morris, C. E., McCarter, K. S., Foreman, C. M., Skidmore, M. L., Montross, S. N., and Sands, D. C.: Geographic, seasonal, and precipitation chemistry influence on the abundance and activity of biological ice nucleators in rain and snow, P. Natl. Acad. Sci., 105, 18854-18859, 2008a.

Christner, B. C., Morris, C. E., Foreman, C. M., Cai, R., and Sands, D. C.: Ubiquity of Biological Ice Nucleators in Snowfall, Science, 319, 1214-1214, 2008b.

Dahms, A.: Nachträge und Bemerkungen zu der Arbeit über Gefrierpunkte binärer Gemenge, Ann. Phys., 296, 119-123, 1896.

DeMott, P., Cziczo, D., Prenni, A., Murphy, D., Kreidenweis, S., Thomson, D., Borys, R., and Rogers, D. C.: Measurements of the concentration and composition of nuclei for cirrus formation, P. Natl. Acad. Sci., 100, 14655-14660. 2003.

Dentener, F., Kinne, S., Bond, T., Boucher, O., Cofala, J., Generoso, S., Ginoux, P., Gong, S., Hoelzemann, J. J., Ito, A., Marelli, L., Penner, J. E., Putaud, J.-P., Textor, C., Schulz, M., van der Werf, G. R., and Wilson, J.: Emissions of primary aerosol and precursor gases in the years 2000 and 1750 prescribed data-sets for AeroCom, Atmos. Chem. Phys., 6, 4321-4344, doi:10.5194/acp-64321-2006, 2006.

Eastwood, M. L., Cremel, S., Wheeler, M., Murray, B. J., Girard, E., and Bertram, A. K.: Effects of sulfuric acid and ammonium sulfate coatings on the ice nucleation properties of kaolinite particles, Geophys. Res. Lett., 36, 1-5, 2009.
Franze, T., Weller, M. G., Niessner, R., and Pöschl, U.: Protein nitration by polluted air, Environ. Sci. Tech., 39, 1673-1678, 2005

Gazit, E.: Global analysis of tandem aromatic octapeptide repeats: The significance of aromatic-glycine motif, Bioinformatics, 18, 880-883, 2002.

Green, W. F.: The "melting-point" of hydrated sodium acetate: solubility curves, J. Phys. Chem. 12, 655-660, 1908.

Gross, D. C., Cody, Y. S., Proebsting Jr., E. L., Radamaker, G. K., and Spotts, R. A.: Distribution, population dynamics, and characteristics of ice nucleation-active bacteria in deciduous fruit tree orchards, Appl. Environ. Microbiol., 46, 1370-1379, 1983.

Gurian-Sherman, D. and Lindow, S. E.: Bacterial ice nucleation: significance and molecular basis, FASEB J, 7, 1338-1343, 1993.

Hammer, U., Harper, D. A., and Ryan, P. D.: PAST: paleontological statistics software package for education and data analysis, Palaeontol. Electron., 4, 9, 2001.

Hoose, C., Kristjánsson, J., and Burrows, S.: How important is biological ice nucleation in clouds on a global scale?, Environ. Res. Lett., 5, 024009, doi:10.1088/1748-9326/5/2/024009, 2010.

Kaneda, T.: Seasonal population changes and characterization of ice-nucleating bacteria in farm fields of central Alberta, Appl. Environ. Microbiol., 52, 173-178, 1986.

Kanji, Z. A., Florea, O., and Abbatt, J. P. D.: Ice formation via deposition nucleation on mineral dust and organics: dependence of onset relative humidity on total particulate surface area, Environ. Res. Lett., 3, 1-7, 2008.

Kawahara, H., Masuda, K., and Obata, H.: Identification of a compound in Chamaecyparis taiwanensis Inhibiting the Ice-Nucleating Activity of Pseudomonas fluorescens KUIN-1, Biosci. Biotech. Biochem., 64, 2651-2656, 2000.

Kawahara, H., Tanaka Y. and Obata H.: Isolation and characterization of a novel ice-nucleating bacterium, Pseudomonas, which has stable activity in acidic solution, Biosci., Biotechnol., Biochem., 59, 1528-1532, 1995.

King, E. O., Ward, M. K., and Raney, D. E.: Two simple media for the demonstration of pyocyanin and fluorescein, J. Lab. Clin. Med., 44, 301-307, 1954.

Knopf, D. A. and Koop, T.: Heterogeneous nucleation of ice on surrogates of mineral dust. J. Geophys. Res., 11, D12201, doi:10.1029/2005JD006894, 2006.

Koop, T., Luo, B., Tsias, A., and Peter, T.: Water activity as the determinant for homogeneous ice nucleation in aqueous solutions, Nature, 406, 611-614, 2000.

Koop, T. and Zobrist, B.: Parameterizations for ice nucleation in biological and atmospheric systems, Phys. Chem. Chem. Phys., 11, 10839-10850, 2009.

Kozloff, L. M., Schofield, M. A., and Lute, M.: Ice nucleating activity of Pseudomonas syringae and Erwinia herbicola, J. Bacteriol., 153, 222-231, 1983.

Kozloff, L. M., Turner, M. A., and Arellano, F.: Formation of bacterial membrane ice-nucleating lipoglycoprotein complexes, J. Bacteriol., 173, 6528-6536, 1991a.

Kozloff, L. M., Turner, M. A., Arellano, F., and Lute, M.: Phosphatidylinositol, a phospholipid of ice-nucleating bacteria, J. Bacteriol., 173, 2053-2060, 1991 b.

Lamarque, J.-F., Bond, T. C., Eyring, V., Granier, C., Heil, A., Klimont, Z., Lee, D., Liousse, C., Mieville, A., Owen, B., Schultz, M. G., Shindell, D., Smith, S. J., Stehfest, E., Van Aardenne, J., Cooper, O. R., Kainuma, M., Mahowald, N., Mc- 
Connell, J. R., Naik, V., Riahi, K., and van Vuuren, D. P.: Historical (1850-2000) gridded anthropogenic and biomass burning emissions of reactive gases and aerosols: methodology and application, Atmos. Chem. Phys., 10, 7017-7039, doi:10.5194/acp10-7017-2010, 2010.

Lindemann, J., Constantinidou, H. A., Barchet, W. R., and Upper, C. D.: Plants as sources of airborne bacteria, including ice nucleation-active bacteria, Appl. Environ. Microbiol., 44, 10591063, 1982.

Marinoni, A., Laj, P., Sellegri, K., and Mailhot, G.: Cloud chemistry at the Puy de Dôme: variability and relationships with environmental factors, Atmos. Chem. Phys., 4, 849-886, 2004, http://www.atmos-chem-phys.net/4/849/2004/.

Mölher, O., DeMott, P. J., Vali, G., and Levin, Z.: Microbiology and atmospheric processes: the role of biological particles in cloud physics, Biogeosciences 4: 1059-1071, 2007.

Möhler, O., Benz, S., Saathoff, H., Schnaiter, M., Wagner, R., Schneider, J., Walter, S., Ebert, V., and Wagner, S.: The effect of organic coating on the heterogeneous ice nucleation efficiency of mineral dust aerosols, Environ. Res. Lett., 3, 025007 , doi:10.1088/1748-9326/3/2/025007, 2008.

Morris, C. E, Glaux, C., Latour, X., Gardan, L., Samson, R., and Pitrat, M.: The relationship of host range, physiology, and genotype to virulence on cantaloupe in Pseudomonas syringae from cantaloupe blight epidemics in France, Phytopathology, 90, 636646, 2000

Morris, C. E., Sands, D. C., Vinatzer, B. A., Glaux, C., Guilbaud, C., Buffière, A., Yan, S., and Dominguez, S: The life history of the plant pathogen Pseudomonas syringae is linked to the water cycle, The ISME Journal, 2, 321-334, 2008.

Morris, C., Sands, D., Vanneste, J., Montarry, J., Oakley, B., Guilbaud, C., and Glaux, C.: Inferring the evolutionary history of the plant pathogen Pseudomonas syringae from its biogeography in headwaters of rivers in North America, Europe, and New Zealand, mBio, 1, 1-11, 2010.

Mortazavi, R., Hayes, C. T., and Ariya, P. A.: Ice nucleation activity of bacteria isolated from snow compared with organic and inorganic substrates, Environ. Chem., 5, 373-381, 2008.

Nemecek-Marshall, M., Laduca, R., and Fall, R.: High-level expression of ice nuclei in a Pseudomonas syringae strain is induced by nutrient limitation and low temperature, J. Bacteriol., 175, 40624070, 1993.

O'Brien, R. D. and Lindow, S. E.: Effect of Plant Species and Environmental Conditions on Ice Nucleation Activity of Pseudomonas syringae on Leaves, Appl. Environ. Microbiol., 54, 2281-2286, 1988.

Orser, C., Staskawicz, B. J., Panopoulos, N. J., Dahlbeck, D., and Lindow, S. E.: Cloning and Expression of Bacterial Ice Nucleation Genes in Escherichia coli, J. Bacteriol., 164, 359-366, 1985.

Pourzand, C. and Tyrrell, R. M.: Apoptosis, the role of oxidative stress and the example of solar UV radiation, Photochem. Photobiol., 70, 380-390, 1999.

Salam, A., Lohmann, U., and Lesins, G.: Ice nucleation of ammonia gas exposed montmorillonite mineral dust particles, Atmos. Chem. Phys., 7, 3923-3931, doi:10.5194/acp-7-3923-2007, 2007.
Sands, D. C., Langhans, V. E., Scharen, A. L., and de Smet, G.: The association between bacteria and rain and possible resultant meteorological implications, J. Hung. Meteorol. Serv., 86, 148$152,1982$.

Sesartic, A., Lohmann, U., and Storelvmo, T.: Bacteria in the ECHAM5-HAM global climate model, Atmos. Chem. Phys., 12, 8645-8661, doi:10.5194/acp-12-8645-2012, 2012.

Shiraiwa, M., Sosedova, Y., Rouvière, A., Yang, H., Zhang, Y., Abbatt, J. P. D., Ammann, M., and Pöschl, U.: The role of longlived reactive oxygen intermediates in the reaction of ozone with aerosol particles, Nature Chem., 3, 291-295, 2011.

Shiraiwa, M., Selzle, K., Yang, H., Sosedova, Y., Ammann, M., and Pöschl, U.: Multiphase chemical kinetics of the nitration of aerosolized protein by ozone and nitrogen dioxide, Environ. Sci. Technol., 46, 6672-6680, doi:10.1021/es300871b, 2012.

Skeie, R., Berntsen, T., Myhre, G., Tanaka, K., Kvalevaag, M., and Hoyle, C.: Anthropogenic radiative forcing time series from preindustrial times until 2010, Atmos. Chem. Phys., 11, 1182711857, doi:10.5194/acp-11-11827-2011, 2011.

Smith, S. J.: Conception E., Andres R. and Lurz J.: Historical Sulfur Dioxide Emissions 1850-2000: Methods and Results. PNNL Research Report, Joint Global Change Research Institute, 8400 Baltimore Avenue College Park, Maryland, 20740, 2004.

Turner, M. A., Arellano, F., and Kozloff, L. M.: Three separate classes of bacterial ice nucleation structures. J. Bacteriol., 172, 2521-2526, 1990.

Vaïtilingom, M., Charbouillot, T., Deguillaume, L., Maisonobe, R., Parazols, M., Amato, P., Sancelme, M., and Delort, A. M.: Atmospheric chemistry of carboxylic acids: microbial implication versus photochemistry, Atmos. Chem. Phys., 11, 8721-8733, doi:10.5194/acp-11-8721-2011, 2011.

Vaïtilingom, M., Attard, E., Gaiani, N., Sancelme, M., Deguillaume, L., Flossmann, A. L., Amato, P., and Delort, A. M.: Long-term features of cloud microbiology at the puy de Dome (France), Atmos. Environ., 56, 88-100, doi:10.1016/j.atmosenv.2012.03.072, 2012.

Vali, G.: Quantitative evaluation of experimental results on the heterogenous freezing nucleation of supercooled liquids, J. Atmos. Sci., 28, 402-409, 1971.

Walcher, W., Franze, T., Weller, M. G., Pöschl, U., and Huber, C. G.: Liquid- and gas-phase nitration of bovine serum albumin studied by LC-MS and LC-MS/MS using monolithic columns, J. Proteome Res., 2, 534-542, 2003.

Yang, H., Zhang, Y., and Pöschl, U.: Quantification of nitrotyrosine in nitrated proteins, Anal. Bioanal. Chem., 397, 879-886, 2010.

Zhang, Y., Yang, H., and Pöschl, U.: Analysis of nitrated proteins and tryptic peptides by HPLC-chip-MS/MS: site-specific quantification, nitration degree, and reactivity of tyrosine residues. Anal. Bioanal. Chem., 399, 459-471, 2011.

Zobrist, B., Marcolli, C., Peter, T., and Koop, T.: Heterogeneous Ice Nucleation in Aqueous Solutions: the Role of Water Activity, J. Phys. Chem. A., 112, 3965-3975, 2008. 